\title{
Teocentryczny model etyki środowiskowej
}

\section{Wstęp}

W zasadzie od samego początku refleksji moralnych jej przedmiotem był człowiek oraz jego czyny w odniesieniu do siebie i ludzi, a także w etykach uprawianych na gruncie teologii również w stosunku do Boga. Jednak w XX wieku sytuacja ta uległa zmianie, wskutek zachwiania równowagi w środowisku, zmuszając wielu etyków i filozofów do rozszerzenia zakresu swoich badań z uwzględnieniem problematyki dotyczącej ochrony środowiska naturalnego. Dzięki temu pojawiła się nowa dyscyplina, określana jako etyka środowiskowa, etyka ekologiczna bądź ekoetyka ${ }^{1}$. Wypracowane przez tę dziedzinę teoretyczne uzgodnienia, zwłaszcza w obszarze wartości, mają stanowić podstawę dla działań praktycznych, związanych $\mathrm{z}$ wychowaniem proekologicznym ${ }^{2}$.

W mojej opinii teocentryzm, jest udanym modelem uprawiania etyki środowiskowej, ponieważ jest w stanie uniknąć pewnych radykalnych rozwiązań, które stały się udziałem opozycyjnych względem siebie - antropocentrycznych ${ }^{3}$ i biocentrycznych ${ }^{4}$ stanowisk w ochronie środowiska. Kierunek ten może okazać się (przynajmniej kolejną) bardzo efektywną drogą zmierzającą do poprawy naszego środowiska społeczno - przyrodniczego, a kto wie, może nawet przysłowiową "trzecią drogą" pomiędzy homocentryzmem i biocentryzmem. Z jednej bowiem strony akcentuje wyjątkowość człowieka w świecie przyrody, z drugiej zaś dopatruje się w przyrodzie wartości, ze względu na Boga, który ją stworzył i ofiarował człowiekowi, jako jej gospodarzowi.

1 Por. Z. SARE£o, Wprowadzenie, (w:) Etyka środowiskowa wyzwaniem XXI wieku. Pod red. J.W. Czartoszewskiego, Warszawa 2002, s.7-8; S. KonstańCzaK, Wybrane zagadnienia ekofilozofii, Słupsk 2005, s. 20-27.

2 Por. W. Tyburski, Główne kierunki i zasady etyki środowiskowej, (w:) Wprowadzenie do filozoficznych problemów ekologii. Pod red. A. Papuzińskiego, Bydgoszcz 1999, s.100; J. Jarox́., Ekologia - Sozologia - Ekofilozofia - Ekoetyka - Ekonomia proekologiczna, Warszawa 1997, s.150-152; Z. HuLL, Problemy filozofi ekologii, (w:) Wprowadzenie do filozoficznych problemów ekologii, op. cit., s. 55-95. 


\section{Zagadnienie teocentryzmu w etyce środowiskowej (ujęcie tomistyczne)}

W dużym uproszczeniu teocentryzm (gr. theos = Bóg + lac. centrum = środek) w etyce to „kierunek nakazujący rozpatrywanie wszelkich działań człowieka, szczególnie moralnych, w odniesieniu do Boga, jako najwyższej i jedynej wartości (Bóg jest tożsamy z summum bonum). Według zwolenników teocentryzmu (np. św. Augustyna i św. Tomasza z Akwinu) tylko taka perspektywa umoźliwia prowadzenie refleksji nad sensem, celem czy przeznaczeniem ludzkiej egzystencji”’5.

Takie pojmowanie teocentryzmu na gruncie etyki środowiskowej nakazuje rozpatrywać wszelkie relacje między działaniami moralnymi człowieka a przyrodą, w odniesieniu do Boga, jako Stwórcy przyrody i kosmosu. Przyroda posiada wartość ze względu na Boga, który ją stworzył i utrzymuje ją nadal w istnieniu. Człowiek jako istota wyjątkowa powinien pełnić rolę dobrego strażnika, gospodarza i opiekuna świata przyrody, którą otrzymał w darze od Stwórcy. Natomiast niszcząc przyrodę sprzeciwiamy się Bogu, a więc grzeszymy i czynimy zło ${ }^{6}$.

3 Antropocentryczne ujęcie etyki środowiskowej, zakłada, iż człowiek stanowi główny punkt odniesienia w rozwiązywaniu etycznych dylematów, dlatego też zobowiązania moralne mamy jedynie wobec ludzi. Przyrodę należy więc chronić tylko ze względu na dobro człowieka. Adwersarze homocentryzmu uważają, iż model ten doprowadził w końcowym efekcie do zachwiania ekologicznej równowagi. Wydaje mi się, iż na obronę takiego stanowiska trzeba zauważyć, iż etyka sama w sobie jest antropocentryczna, gdyż tylko ludzie mają możliwość odróżnienia dobra od zła, dlatego też tylko od ludzi wymaga się odpowiedzialności za czyny, również te wobec przyrody. Ponadto wydaje mi się, iż za kryzys ekologiczny odpowiedzialny jest egocentryczny model ekoetyki, gdyż konsekwentny antropocentryzm postuluje ochronę środowiska przyrodniczego, ponieważ jej degradacja przyczynia się pośrednio do niszczenia człowieka, a więc narusza jego dobro.

4 Przedstawiciele ekoetyki biocentrycznej, uważają, iż człowiek nie jest jakąś uprzywilejowaną częścią biosfery i wszelkie kontakty ze środowiskiem powinien ukladać według scenariusza, w którym zasada dominacji gatunkowej powinna ustąpić zasadzie równości i współdziałania. Wedle zwolenników etyki zorientowanej biocentrycznie, tradycyjna etyka, ograniczająca swe zainteresowania do sfery stosunków międzyludzkich, jest w istocie akceptacją szowinizmu gatunkowego.

5 L. Gawor, Teocentryzm (hasło), (w:) Mały słownik etyczny. Pod red. S. Jedynaka, Bydgoszcz 1999, s. 265.

6 Por. M. Ciszer, Antropocentryczne czy teocentryczne podstawy chrześcijańskiej etyki środowiskowej?, (w:) Etyka środowiskowa wyzwaniem XXI wieku. Pod red. J.W. Czartoszewskiego, Warszawa 2002; M. CIszer, Antropoprioryczna koncepcja chrześcijańskiej etyki środowiskowej oraz jej implikacje w bezpieczeństwie ekologicznym, (w:) Ekofilozofia, bioetyka, etyka biznesu. Aktualne problemy wspólczesności. Pod red. J. Jaronia, Siedlce 2004; M. Ciszek, Etyka środowiskowa (ekologiczna) jako nowa dziedzina etyki na podstawie polskiej literatury przedmiotu, (w:) Filozofia polska w okresie transformacji ustrojowej. Pod red. W. Słomskiego, Siedlce 2003; M. Ciszek, Wokól wybranych idei chrześcijańskiego humanizmu ekologicznego, (w:) Veritas sed doctrina multiplex. Ksiegga pamiątkowa ku czci prof dr hab. Józefa Jaronia. Pod red. W. Słomskiego i M. Ciszka, Siedlce 2003. 
Niestety w literaturze ekofilozoficznej można spotkać się (moim zdaniem z niesłusznymi) opiniami, obciążąącymi spuściznę judeo-chrześcijańską za kryzys ekologiczny. Zawinić miał przy tym charakterystyczny dla tej tradycji skrajnie pojmowany antropocentryzm. Tego najlepszym przykładem mają być słynne fragmenty z księgi Rodzaju, w którym Bóg daje człowiekowi wszystkie zwierzęta zamieszkujące naszą planetę oraz samą Ziemię w posiadanie (Rdz 1:26; Rdz 1:28).

Naturalnie bibliści odrzucili taką antyekologiczną interpretację Biblii wskazując, na wiele fragmentów, w których jak najbardziej wyeksponowane są treści ukazujące wartość przyrody, warto przypomnieć choćby jeden, również z Księgi Rodzaju, w którym zawarta jest nauka, że po tym jak Bóg stworzył ziemię, zobaczył, że była dobra (Rdz 1, 12), co znaczy, że ludzie z Bożego dzieła muszą korzystać w sposób odpowiedzialny.

W miejscu tym jednak nasuwa się fundamentalne pytanie: czy etyka chrześcijańska jest rzeczywiście antropocentryczna? Poniżej postaram się udzielić odpowiedzi.

Nie ulega wątpliwości, iż katolicka etyka środowiskowa w swoich założeniach akcentuje wyjątkowość człowieka na tle innych bytów przyrodniczych i sytuuje człowieka - osobę ludzką w centrum swojego zainteresowania, jest więc w swoich założeniach antropocentryczna. Jest to jednak antropocentryzm, który ma swoją własną specyfikę, nie mającą wiele wspólnego z potocznym, zresztą na ogół pejoratywnym wydźwiękiem tego terminu, na co zwrócili uwagę: Józef M. Dołęga, Wojciech Bołoz oraz inni katoliccy etycy ${ }^{7}$.

$\mathrm{Na}$ samym wstępie warto przypomnieć, że pojęcie antropocentryzmu ma szeroki zakres semantyczny, dlatego termin ten rozpatruję w dwojaki sposób, wydzielając w nim dwie odmiany (stanowiska wobec przyrody). Pierwszą z nich postanowiłem nazwać antropocentryzmem absolutnym, które przeciwstawiam antropocentryzmowi relatywnemu akcentującemu umiarkowane podejście w czerpaniu z zasobów przyrody.

Zwolennicy tej pierwszej skrajnej orientacji traktują środowisko naturalne w sposób instrumentalny. Podejście takie jest pochodną konsumpcyjnego, stylu życia kładącego akcent tylko na materialnej stronie egzystencji ludzkiej, pomijając prawie calkowicie wymiar duchowy. Taka skrajna postawa jest więc z gruntu wypaczona i niechrześcijańska. Już na tej podstawie można zadać kłam twierdzeniom, iz tradycja chrześcijańska jest nieekologiczna.

Por. J.M. DoŁĘGA, Ekologia w teologii i filozofii chrześcijańskiej, (w:) Wprowadzenie do filozoficznych problemów ekologii, op. cit., s. 133-163; M. Ciszek, Józefa M. Dołęgi koncepcja ekofilozofii systemowej, „Doctrina”, 2/2005, s. 337-344; W. Bołoz, Biblinne podstawy ekoteologii, (w:) Ochrona środowiska społeczno - przyrodniczego w filozofii i teologii. Pod red. J.M. Dołęgi, J.W. Czartoszewskiego, A. Skowrońskiego, Warszawa 2001, s. 342-358; 
Natomiast przedstawiciele tego drugiego umiarkowanego stanowiska, traktują przyrodę jako dobro wspólne, jest więc to ujęcie jak najbardziej proekologiczne, które zaprzecza nieograniczonej władzy człowieka nad przyrodą w myśl hasła odpowiedzialnego powiernictwa oraz opiekuństwa. Właśnie w takim względnym ujęciu należy rozumieć antropocentryczny charakter katolickiej etyki i filozofii ekologicznej.

Chrześcijańscy ekoetycy podkreślają, iż teologia stworzenia ukazuje nam wyjątkowe ekologiczne walory katolicyzmu. Zwracają przy tym uwagę na takie teologiczne argumenty (prawdy), jak: prawdę o Bogu Stwórcy, prawdę o stworzeniu wszechświata oraz prawdę o stworzeniu czlowieka. Zapoznanie się z prawdą o Bogu Stwórcy prowadzi bowiem do zrozumienia, że Bóg stwarza świat: „z miłości, dobroci, mądrze, „z niczego", z wolnej woli i podtrzymuje go w istnieniu oraz nim kieruje, pozwala się poznać poprzez stworzone dzieła, aczkolwiek pozostaje wobec nich transcendentny"8. Z kolei przybliżenie prawdy o stworzeniu wszechświata daje możliwość zastanowienia się nad pięknem świata oraz dobrem, porządkiem, różnorodnością i bogactwem, jakie w nim można odnaleźć, to zaś w efekcie prowadzi do obdarzenia szacunkiem Bożego dzieła. Natomiast prawda o stworzeniu człowieka przypomina, iż został on stworzony przez Stwórcę na swoje podobieństwo, obdarzając go rozumem oraz wyjątkową przyjaźnią z Bogiem, dlatego też w świecie zajmuje uprzywilejowaną pozycję, której nie sposób podważać 9 .

Na tej podstawie należy uznać, iż antropocentryzm Starego Testamentu jest antropocentryzmem relatywnym, gdyż właściwie idzie tutaj o teocentryczną, a nie homocentryczną wizję świata, gdyż Bóg stanowi jej centralny punkt odniesienia.

To rozróżnienie jest również charakterystyczne dla filozofii tomistycznej. Chrześcijańska antropologia jest w zasadzie teocentryczna, oraz chrystocentryczna, ponieważ katolicyzm rozpatruje człowieka w aspekcie nadprzyrodzonym oraz przez pryzmat całej ekonomii zbawienia, która swe apogeum znajduje w dziele Odkupienia przez Jezusa Chrystusa. Chrześcijaństwo od samego początku, opierając się na Objawieniu, stanęło na stanowisku, że człowiek jest dziełem Boga i przeznaczonym do obcowania z Bogiem. Posiada on nieśmiertelną duszę duchową, obdarzoną rozumem i wolną wolą, bezpośrednio pochodzącą od Boga, która ożywia ciało. Celem człowieka jest więc zjednoczenie z Bogiem za życia przez łaskę, wysłużoną mu przez Chrystusa, natomiast po śmierci bezpośrednie zjednoczenie ze Stwórcą równoznaczne z osiągnięciem pełni szczęścia ${ }^{10}$.

\footnotetext{
${ }^{8}$ S. Dziekoński, Wychowanie ekologiczne w religii chrześcijańskiej, (w:) Podstawy kultury ekologicznej. Pod red. J.M. Dołęgi, Warszawa 2002, s. 60.

Ibidem.

10 G. DogIEL, Antropologia filozoficzna, Kraków 1992, s. 14.
} 
Antropocentryczne ujęcie filozofii człowieka tak naprawdę jest dziełem epoki nowożytnej, przede wszystkim renesansu, który rozpatruje fenomen człowieka w oddzieleniu od Boga, którego miejsce zajmuje ludzka autonomia, pojmowana często w sposób zbyt skrajny. ${ }^{11} \mathrm{~W}$ tym laickim ujęciu antropocentryzmu należy doszukiwać się przyczyn ekologicznego kryzysu.

Osobiście jestem zwolennikiem takiego ujęcia katolickiej etyki środowiskowej, które nie stanowiłoby jednak skrajnej opozycji, wobec antropocentryzmu, lecz raczej jego dopełnienie. Takie teocentryczne ujęcie etyki środowiskowej może okazać się swoistą trzecią drogą, która jest w stanie uniknąć kontrowersji jakie stały się udziałem antagonistycznych względem siebie obozów zwolenników biocentryzmu i antropocentryzmu.

Warto zauważyć, iż Jan Paweł II, często podkreślał, że przyroda jest darem Boga i dlatego też umiejętne gospodarowanie jej zasobami jest nakazem moralnym. Człowiek został przez Boga postawiony na czele stworzenia, po to aby o nie dbał, a także posługiwał się nimi dla własnych potrzeb, jak uczy nas Biblia. Natomiast wszelkie uchybienia w tym zakresie stanowią ciężki grzech wobec Stwórcy, czyli tzw. grzech ekologiczny ${ }^{12}$.

W teocentryzm wpisana jest więc zasada poszanowania przyrody. Jak zauważył J.L. Lorda „Natura w swej całości cechuje się osobliwą godnością, która polega na tym, że jest odbiciem samego Boga. Odbiciem, które należy szanować, chronić i zachowywac'"13. Etycy odwołujący się do ujęć tomistycznych, zwracają jednak uwagę, iż nie należy zapominać, iż człowiek jest bytem wyjątkowym, któremu przysługuje wyjątkowa wartość.

Dlatego należy przedstawić antropologiczne założenia, które legły u podstaw chrześcijańskiej etyki ochrony przyrody, która lokuje człowieka w pozycji wartości autotelicznej wobec innych bytów przyrodniczych.

\section{Antropologiczne podstawy etyki środowiskowej w ujęciu tomistycznym}

Z perspektywy klasycznej filozofii człowiek jest unikalnym bytem psychofizycznym i jedynym organizmem zamieszkującym Ziemię, o którym można byłoby orzec, iż jest osobą, a co za tym następuje najwyższą formą bytu. Jest to fundamentalne założenie dla tomistycznej etyki ekologicznej, ponieważ oznacza, że człowiek - osoba jest również najdoskonalszym bytem w przyrodzie oraz wartością autoteliczną systemu.

Ibidem, s. 15 .

12 Zob. J. DęBowski, Filozoficzne źródla refleksji ekologicznych, Olsztyn 1996, s. 127.

13 J.L. Lorda, Moralność - sztuka życia, Warszawa - Ząbki 1999, s. 119-120. 
Mamy tu do czynienia z dwoma rodzajami argumentów na poparcie tezy o wyjątkowości człowieka w przyrodzie. Mam tu na myśli argumentację teologiczną i filozoficzną. Pierwszy z nich to argument natury teologicznej, który podkreśla, iż to co odróżnia człowieka od reszty bytów przyrodniczych to istnienie w nim unikalnego pierwiastka duchowego. Bardzo ważny jest również aspekt chrystologiczny zagadnienia, według którego Jezus Chrystus poprzez swą zbawczą mękę wyniósł ludzką naturę do rangi unikalnej, której przeznaczeniem jest świętość w aspekcie zbawczym i moralnym. Człowiek przeznaczony jest do duchowego i moralnego samodoskonalenia, a tego od zwierząt przecież nie wymagamy.

Adwersarze katolickiej etyki, rekrutujący się ze środowisk ukierunkowanych biocentrycznie polemizują z taką wizją ludzkiej natury, dlatego też uważam, iż argumentację teologiczną, koniecznie należy uzupełnić argumentacją filozoficzną. Zgadzam się więc $\mathrm{z}$ tymi katolickimi myślicielami, którzy postulują dokonanie filozoficznej analizy „wewnętrznej wartości” człowieka, mającej na celu ustalenie, na czym ta „wartość" polega i w jakiej relacji pozostaje do „wartości” pozostałych bytów przyrodniczych ${ }^{14}$. Bez takiego filozoficznego wglądu, niemożliwe jest właściwe uprawianie etyki środowiskowej ${ }^{15}$.

Katoliccy myśliciele zwracają uwagę, iż wewnętrzna wartość człowieka, w duzej mierze wynika $z$ faktu, iz jest on bytem wyjątkowym w świecie przyrody. To co niewątpliwie wyróżnia człowieka od innych organizmów jest ludzki psychizm, który warto poddać filozoficznej analizie. Od tego bowiem, jaką formę bytu psychizm ten reprezentuje, zależy odpowiedź, kim jest człowiek i co za tym idzie jak powinien kształtować się jego stosunek do środowiska przyrodniczego ${ }^{16}$.

W tym miejscu dotykamy fundamentalnej kwestii. Sfera psychiczna, mentalna człowieka jest czymś unikatowym, ponieważ rodzi świadomość doświadczania własnego człowieczeństwa. Jak zauważył M.A. Krąpiec podstawowe ludzkie doświadczenie „bycia człowiekiem" jest doświadczeniem własnej osoby, ponieważ byt osobowy jawi się jako „ja”, podmiot istniejący „w sobie”. „Samoświadomość człowieka, czyli bezpośrednie dotarcie poznawcze do bytu - podmiotu, zdolnego do wejścia w kontakt z całym światem, wraz z poznawczym doświadczeniem $<<$ siebie $>>$ - własnego $<<$ ja $>>$, przeciwstawionym przedmiotowi poznania - zasadniczo wyróżnia i odróżnia człowieka od wszelkich innych bytów poznających, zwierzęcych"17.

14 Zob. T. Ślıipko, A. Zwoliński, Rozdroża ekologii, Kraków 1999, s.123-124.

15 W tej części pracy korzystałem ze szczególnie cennych analiz ks. Tadeusza Ślipki, o. Mieczysława Alberta Krąpca oraz ks. Julisława Łukomskiego w tej materii.

16 T. ŚlPKo, A. ZwolińsKi, Rozdroża ekologii, op. cit., s. 124.

17 M.A. Krąiec, Kim jest czlowiek?, (w: M.A. Krąpiec, Z.J. ZdybickA, A. Maryniarczyk, P. JARoszYŃski, Wprowadzenie do filozofi, Lublin 2003, s.313. 
Niezwykle cenne są analizy pokładów ludzkiej psychiki, w tym źródła ludzkiej samoświadomości, jakich dokonał wspominany już ks. T. Ślipko. W jego opinii człowiek jest istotą wyjątkową w świecie przyrody, której nie sposób odmówić wewnętrznej wartości, jakiej nie znajdziemy u innych ziemskich, pozaludzkich form bytowania.

Filozof ów, zwrócił uwagę, iż w introspektywnym doświadczeniu jawi się nam bogaty świat różnych przejawów życia psychicznego człowieka, wśród których należałoby wymienić najbardziej typowe: szeroki wachlarz uczuć, tworów wyobraźni, zapisów pamięci oraz rozległy nurt aktów poznawczo - dążeniowych. Ponadto w sferze uczuć oraz aktów poznawczo - dążeniowych należałoby wyodrębnić dwa poziomy poznania: zmysłowe i racjonalne (intelektualne), które wyzwalają odpowiadające im dążenia $\mathrm{w}$ formie zmysłowych aktów oraz aktów rozumnej woli. Antropolodzy katoliccy właśnie w rozumnej sferze ludzkiej aktywności psychicznej upatrują główny nurt życiowych przeżyć człowieka, nie negując przy tym bynajmniej wymiaru zmysłowego. Na potwierdzenie swojego stanowiska przytaczają argument, że siłą rozumu można stłumić nawet bardzo gwałtowne popędy. W tej właśnie sferze należy doszukiwać się istotowej różnicy między człowiekiem a innymi bytami ożywionymi oraz podstawy dla niezbywalnej, wewnętrznej wartości człowieka ${ }^{18}$.

W miejscu tym warto oddać głos filozofowi, który zauważa, iż „istotową treść człowieczeństwa określa substancjalna jedność pierwiastka niematerialnego (duchowego) z pierwiastkiem materialnym (cielesnym). Wypływająca $\mathrm{z}$ tego źródła właściwa człowiekowi dynamika rozwojowa przejawia się w bogatym świecie duchowych przeżyć człowieka i tworzonej przezeń kultury, które w sumie - nawiązując do języka inkluzjonizmu ekologicznego - można określić jako wewnętrzną wartość człowieka. Człowiek jest więc bytem nie tylko innym, ale ponadto istotowo u samych korzeni ukonstytuowanym jako byt autonomiczny, samowiedny i samowładny, działający we własnym imieniu (sui iuris) i na własną odpowiedzialność, jest - krótko mówiąc - osobą!"'19.

Zwolennicy etyki biocentrycznej, uważają iż takie tradycyjnie katolickie ujęcie zagadnienia jest nieobiektywne, albowiem $w$ świecie pozaludzkich form życia dostrzec można swoiste formy wewnętrznego życia psychicznego.

Naturalnie nie należy temu przeczyć. Na marginesie należy zauważyć, iż badania z zakresu współczesnej etologii (nauki o zachowaniu zwierząt) i psychologii zwierząt, zdają się potwierdzać występowanie podobnych cech u zwierząt. Warto odnotować publikację niemieckiego zoologa i psychologa Vitusa B. Droschera, która ukazała się kilka lat temu w Polsce. Udowadnia on, że w świecie zwierząt można odnaleźć zjawiska psychologiczne i cechy przypisywane wyłącz-

\footnotetext{
18 T. Ślpko, A. Zwoliński, Rozdroża ekologii, op. cit., s. 125-126.

19 Ibidem, s. 128-129.
} 
nie ludziom - miłość, związki małżeńskie, poczucie piękna, odwagę, tchórzostwo, smutek, a także potrzebę życia w zgodzie ze środowiskiem przyrodniczym ${ }^{20}$.

Katoliccy filozofowie podkreślają, iż pomimo całej niezaprzeczalnej „zmyślności" zwierząt są one jednak zdeterminowane w swoich zachowaniach charakterystycznych dla egzemplarzy konkretnego gatunku. Z tego też powodu wśród zwierząt nie sposób odnotować zjawiska zewnętrznego czy też wewnętrznego postępu, dokonanego wskutek własnych aktów poznawczo - dążeniowych. Zwierzęta nie rozwinęły dzięki własnej wewnętrznej inicjatywie swego życia psychicznego czy duchowego co pozwoliłoby im na wykształcenie własnej, odrębnej i specyficznej zwierzęcej kultury. Poszczególni przedstawiciele zwierzęcych gatunków, dajmy na to pies, lew czy kot zachowują się identycznie, jak ich przodkowie z okresu kamienia łupanego. Dzieje się tak dlatego, ze ich poznanie bazuje jedynie na zmysłach. Brak zaś refleksji powoduje, ze zwierzęta nie wykraczają poza konkretne cechy poznawanego przedmiotu, nawet wówczas, gdy wznoszą się na poziom uogólnień pewnych typów zbiorowych (np. kot odróżnia psa, przed którym ucieka czy od myszy, którą stara się schwytać). ${ }^{21}$

Jak zwrócił uwagę M.A. Krąpiec, zwierzę co prawda posiada świadomość swego przedmiotu poznania, ponieważ jest w stanie dostosować się do struktury i działania określonego przedmiotu, to jednak tego typu reakcje są wrodzone ponieważ wynikają z ich zdeterminowanej natury. Konkretny materialny przedmiot wywołuje inne reakcje poznawcze np. u ptaka, wiewiórki czy u psa. Dzieje się tak dlatego, że reakcje te są „uzależnione od odpowiedniej natury każdego ze zwierząt, które wybierają w przedmiocie to tylko, co jest jakoś potrzebne dla ich natury jednostkowej i gatunkowej. Wszystkie inne cechy realne przedmiotu nie budzą w nich żadnego zainteresowania. (...) W reakcji poznawczej na odpowiednie bodźce zwierzę - wedle miary swej natury - jest całkowicie <<przy >> swoim przedmiocie, bez dystansu, bez ukazania jakiegoś $<<j a>>$ transcendują cego przedmiot $\mathrm{i}<<$ siebie $>>$ samego. Jest tylko sprawnym, niezreflektowanym źródłem i ośrodkiem działania zgodnie z możliwościami swej natury" 22.

Można więc uznać, iż ludzie dzięki rozumnej naturze przekroczyli biologiczny determinizm, jaki odziedziczyli w toku procesu ewolucji. W związku z tym są w stanie dokonywać wyborów moralnych, co zdaje świadczyć na korzyść tezy, że człowiek powinien stanowić wartość autoteliczną w systemie etyki środowiskowej.

Zwraca na to również uwagę J. Łukomski podkreślając, iż sama przyroda nie daje nam wzorów zachowania się i nie jest wcale taka sielska, jak chcą jej miłośnicy. Kukułki podrzucają własne potomstwo, wiewiórki niszczą gniazda innych

\footnotetext{
20 Zob. V. B. Droscher, Ludzkie oblicze zwierzat, Warszawa 1999.

21 T. Slipko, A. Zwoliński, Rozdroża ekologii, op. cit., s.130.

22 M.A. KrąPIEC, Kim jest czlowiek?, op. cit., s.314.
} 
ptaków. Zdarza się również, że tygrysy czy inne zwierzęta pożerają swoje dzieci. Jednakże $w$ świecie zwierzęcym panują działania płynące $z$ instynktów i nie podlegają kwalifikacji moralnej. Owszem wśród ludzi można odnotować również wiele negatywnych zachowań, lecz są one odstępstwem od obowiązujących norm, które już z samej natury są nieetyczne, patologiczne. Dzieje się tak dlatego, że winą, odpowiedzialnością moralną, można obarczyć jedynie człowieka, ponieważ jest w stanie odróżnić dobro od zła i rozumie, że ma powinność moralną względem drugiej osoby ${ }^{23}$.

Na podstawie powyższych rozważań należy stwierdzić, iż u podstaw tomistycznej etyki środowiskowej leży idea wyższości człowieka nad przyrodą, ponieważ jest on wyposażony w duchowy substancjalny pierwiastek istnienia i działania, który przekształca człowieka w osobowy podmiot, świadomy własnej godności i zdolny do realizacji własnych planów. Takiego zaś charakteru nie sposób przypisać całej ożywionej przyrodzie, dlatego też człowieka należy uznać za wartość autoteliczną ${ }^{24}$, tylko on może być podmiotem moralności.

W takim ujęciu przyroda posiada więc wartość instrumentalną ponieważ, niszcząc przyrodę; faunę, florę przyczyniamy się tym samym do unicestwienia człowieka, narażając go na śmierć i choroby.

$\mathrm{Z}$ drugiej jednak strony należy pamiętać, że w teocentrycznym paradygmacie ekoetyki pojawia się zasadnicza kwestia, która dowartościowuje świat przyrody. Natura jest bowiem odbiciem Bożej godności. Bóg jako Stwórca przyrody nadal ją podtrzymuje $w$ istnieniu, czlowiek zaś jest szczególnie odpowiedzialny za pielęgnowanie tego stanu i umiarkowanego, przemyślanego korzystania z jej zasobów. Należy jednak pamiętać, iż godność natury jest mniejszej rangi niż niezbywalna godność człowieka, która zdaniem niektórych katolickich ekoetyków stanowi normę moralną systemu ${ }^{25}$.

Idąc takim tokiem rozumowania uznałem, że godność ludzka, jest naczelną normą dla chrześcijańskiej etyki ochrony środowiska naturalnego i co za tym idzie stanowi również jej przedmiot materialny. Podobny pogląd reprezentuje J. Łukomski oraz inni etycy katoliccy.

W ich bowiem ujęciu człowiek zasługuje na szczególnie „honorowe” traktowanie. I nie jest to spowodowane tym, że jest on przedstawicielem gatunku homo sapiens. Godność człowieka jest dlatego naczelną normą katolickiej etyki środowiskowej, ponieważ ludzie są osobami. ${ }^{26}$

\footnotetext{
23 J. ŁUKoмski, Podstawy chrześcijańskiej etyki środowiska naturalnego, (w:) Ochrona środowiska w filozofi i teologii. Pod red. J.M. Dołegi i J.W. Czartoszewskiego, Warszawa 1999, s.179-180.

24 T. ŚLIPKO, Ekologia między filozofią a ideologia, (w:) Między filozofia przyrody a ekofilozofia. Pod red. A. Latawiec i G. Bugajaka, Warszawa 1999, s. 173-174.

25 Zob. J. Łukomski, Podstawy chrześcijańskiej etyki środowiska naturalnego, op. cit., s.182-186.

26 A. Szostek, Pogadanki z etyki, Częstochowa 1998, s.103.
} 
Jak zauważył Andrzej Szostek, takie ujęcie pociąga za sobą odpowiednie skutki między innymi takie, ,że gdybym poznał osoby, które nie są ludźmi (aniołów, przybyszów z kosmosu), to powinienem odnosić się do nich tak, jak do ludzi, choć z genetycznego punktu widzenia ludźmi nie są ${ }^{27}$.

Na podstawie wyżej wymienionych związków zachodzących między człowiekiem i przyrodą, istnieje uzasadniona powinność uznania wartości naturalnego środowiska człowieka. Podzielam opinię J. Łukomskiego, że uznając wartość (dobroć) środowiska, musimy uznać dobroć ekologiczną jego głównego mieszkańca - człowieka. Szacunek okazywany naturze, która jest siedliskiem życia człowieka, jest pośrednio wyrazem uznania dla jego godności. Dlatego też, gdy następuje ingerencja człowieka w przyrodę, ważna jest świadomość, na ile tego rodzaju działanie potwierdza godność osoby, na ile zaś jej zaprzecza ${ }^{28}$. Jak uczy nas Jan Paweł II: „Szacunek dla życia, a przede wszystkim, dla ludzkiej godności, jest podstawową zasadą postępu ekonomicznego, przemysłowego i naukowego. (...) „Najgłębszą i najpoważniejszą implikacją moralnej kwestii ekologicznej jest brak szacunku dla życia, który charakteryzuje wiele zachowań sprzecznych z zasadami ochrony środowiska" ${ }^{29}$.

Cenne wypowiedzi Jana Pawła II na tematy ekologiczne pozwalają spojrzeć na problemy ochrony środowiska z perspektywy nie tylko stricte etycznej ale również i teologiczno-moralnej. Następna część mojej pracy podejmuje właśnie to zagadnienie ${ }^{30}$.

\section{Teologiczno-moralne problemy ochrony środowiska społeczno-przyrodniczego}

Wybrane, teologiczno-moralne problemy ochrony środowiska społeczno-przyrodniczego postanowiłem zacząć od przedstawienia prawa naturalnego, które jest wyznacznikiem moralnego Bożego ładu w świecie - również w wymiarze ekologicznym. Następnie podjąłem problematykę sumienia ekologicznego, które jest „stróżem” moralności także w stosunku do ludzkich zachowań w środowisku przyrodniczym, i stara się ochronić człowieka przed popełnieniem grzechu ekologicznego, który przecież jest jedną z form nieposłuszeństwa wobec Boga. Bardzo ważne jest również kształtowanie odpowiednich trwałych postaw wobec drugiego człowieka i przyrody cechujących się milością, roztrop-

\footnotetext{
Ibidem.

28 J. Łukomski, Podstawy chrześcijańskiej etyki środowiska naturalnego, op. cit., s.184-185.

29 Jan Pawee II, Orędzie na XXIII Światowy Dzień Pokoju, Rzym 1990, p.7.

30 Por. J. Grzesica, Ochrona naturalnego środowiska. Problem teologiczno - moralny, Katowice 1983; M. CISZE K, Ekologiczne aspekty katolickiej teologii moralnej, „Studia Ecologiae et Bioethicae", 2/2004, s. 317-325.
} 
nością i umiarkowaniem, jak uczy nas aretologia. Na zakończenie tego paragrafu umieściłem Dekalog ekologiczny, którego zasadom chrześcijanie powinni hołdować w codziennym życiu.

\subsection{Prawo natury w płaszczyźnie ekologicznej}

W literaturze ekoteologicznej, przyjmuje się, iż ujęcie prawa naturalnego w płaszczyźnie ekologicznej, podkreśla, ze pomimo faktu, że człowieka i resztę organizmów przyrodniczych łączy te same materialne podłoże, to tworzą jednak dwa odrębne światy. Człowiek żyje w przyrodzie, z przyrodą i dzięki niej, ale nie jest bez reszty przyrodą, ponieważ ją przerasta, a więc w pewnym sensie jest $<<$ poza przyrodą $>>31$.

Treści tak pojmowanego prawa naturalnego oscylują wokół człowieka, zwłaszcza jego godności, życia, szeroko pojętej twórczości, religijności oraz społecznego wymiaru bytowania - które mają również wymiar ekologiczny. Płaszczyzna takiego podejścia zasadza się na założeniu, że świat stworzony przez Boga nie jest przypadkiem i chaosem i nawet dla ateisty, który co prawda nie wierzy w Boga, lecz przyjmuje istnienie porządku w świecie, wystarcza do uznania przez niego prawa moralnego, które również nakazuje dbać o wszystkie elementy, które tworzą środowisko społeczno - przyrodnicze ${ }^{32}$.

Dlatego też rozwój myśli ludzkiej powinien prowadzić do zmiany naszego podejścia ekologicznego wobec otaczającej nas rzeczywistości, jaką jest środowisko naturalne, niszcząc bowiem przyrodę, niszczymy również zakotwiczonego w niej człowieka.

O ile prawo naturalne jest wyznacznikiem ładu moralnego, o tyle sumienie jest stróżem moralności również w wymiarze ekologicznym.

\subsection{Ekologiczne ujęcie syneidesjologii (nauki o sumieniu)}

Andrzej Papuziński definiuje sumienie ekologiczne „jako ów moment w doświadczeniu wolności przez człowieka, w którym uświadamia on sobie odpowiedzialność za życie w każdej postaci: antroposferę, zoosferę, biosferę i geosferę; za cały potencjał genetyczny życia na naszej planecie, za utrzymanie liczebności populacji wszystkich form życia, przynajmniej zapewniającej ich przetrwanie w naturalnych warunkach i za nienaruszoną równowagę procesów naturalnych"33.

31 T. ŚLIPKo, Prawo naturalne jako podstawa szacunku człowieka dla życia i przyrody, „Ethos”, 1994, nr 1-2 (25-26), s. 89.

32 M. Ozorowski, Teologiczne podstawy kultury ekologicznej, (w:) Podstawy kultury ekologicznej, op. cit., s. 45.

33 A. PA PUZIŃski, Polityka a perspektywy sumienia ekologicznego, (w:) Ziemia domem czlowieka, pod red. L. Krakowiaka, Warszawa 1992, s. 21. 
W takim właśnie kontekście należy również mówić o sumieniu ekologicznym i potrzebie jego kształtowania, a także jego wychowania na gruncie chrześcijańskim - na co zwraca uwage Katechizm Kościoła Katolickiego ${ }^{34}$. Jest to możliwe, ponieważ z punktu widzenia chrześcijańskiej etyki ekologicznej niszczenie środowiska jest czynem, który zasmuca Boga. Teolodzy, etycy i pedagodzy - katecheci katoliccy, którzy podejmują problematykę sumienia ekologicznego, skłaniają do refleksji, czy możemy z całą pewnością powiedzieć, że „nie mamy na sumieniu niczyjego życia” (Dz 20, 26).

Konieczny i aktualny jest więc postulat odpowiedniego - ekologicznego rachunku sumienia, który ma na celu uświadomić chrześcijaninowi czy aby jego działania nie sprzyjają dewastacji przyrody. Warto nadmienić, iż w naszym kraju opracowano dwa wzory ekologicznych rachunków sumienia ${ }^{35}$.

Sumienie ekologiczne stara się ochronić człowieka przed popełnieniem grzechu przeciwko przyrodzie i bliźniemu, który w niej przecież egzystuje.

\subsection{Grzech ekologiczny}

Na ogół problem grzechu ekologicznego rozpatrywany jest w nawiązaniu do przesłania biblijnego, że Bóg stworzył świat doskonały, wszystko było w nim dobre, w tym również czlowiek i jego kondycja moralna. Dopiero grzech zniweczył ten stan harmonii. Złe uczynki wobec przyrody są więc grzechem popelnionym w stosunku do Boga.

Na płaszczyźnie teologiczno - moralnej analizy grzechu ekologicznego dokonał Jerzy Bajda ${ }^{36}$. Uczony ten specyfikę grzechu ekologicznego ujmuje w kategoriach ludzkiego nieposłuszeństwa wobec Boga jako stwórcy świata i jego porządku (prawa naturalnego), w tym również i człowieka.

Pojęcie grzechu ekologicznego zakłada więc, że istnieje porządek ustalony przez Boga, w którym określono prawdę i przeznaczenie wszystkich stworzeń, zaś człowiek zobowiązany jest moralnie wypełniać ten plan. Możliwość popełnienia grzechu ekologicznego wynika więc z faktu, że na człowieku spoczywa unikatowa odpowiedzialność za świat na podstawie powołania stwórczego, jakie jest zawarte w Księdze Rodzaju. Człowiek jest jakby namiestnikiem Boga w świecie przyrody, w którym sprawuje władzę na mocy Bożego mandatu. Nie może

34 Por. Katechizm Kościoła Katolickiego, Poznań 1994, n. 1784.

35 Por. J.W. Czartoszewski, Ekologiczne rachunki sumienia, (w:) Ochrona środowiska w filozofii i teologii, op. cit., s. 243-251.

36 Por. J. BAJDA, Grzech ekologiczny (Próba podejścia do zagadnienia), (w:) Z czlowiekiem i przyroda (wreszcie) po ludzku, pod red. B. Wójtkiewicz, Wisełka 1995, s. 71-80; J. BAJDA, Grzech ekologiczny, (w:) Ochrona środowiska w filozofii i teologii, pod red. J.M. Dołegi, J.W. Czartoszewskiego, Warszawa 1999 , s. 222-242. 
jednak człowiek przypisywać sobie boskości (czy jakiemuś innemu stworzeniu), gdyż w Biblii nie ma mowy o absolutnym władztwie człowieka, lecz o takim używaniu ziemi, które ogólnie wynika $\mathrm{z}$ ogólnego powołania ludzkości jako $<<$ rodziny Bożej>>" ${ }^{37}$.

Na podstawie powyższych uwag J. Bajda przedstawia istotę grzechu ekologicznego, nawiązując przy tym do Biblii, podkreślając przy tym, że "grzech ukazany na kartach Biblii ma zarazem swoją postać <<ekologiczną〉>, można powiedzieć, że grzech jako taki jest także ze swej istoty i z konieczności grzechem ekologicznym, jest złem, które burzy ludzki świat" i całą jego strukturę i harmonię ${ }^{38}$

Dlatego tak ważne jest kształtowanie u chrześcijanina odpowiednich sprawności moralnych mających na celu poszanowanie środowiska społeczno - przyrodniczego.

\subsection{Ekologiczne aspekty aretologii}

W teologii moralnej podkreśla się, że aretologia zawiera w sobie charakterystykę poszczególnych cnót teologicznych (teologalnych) i kardynalnych. Warto więc zauważyć, iż zająłem się tylko tymi spośród całego katalogu cnót, które z powodzeniem można wykorzystać w chrześcijańskiej etyce środowiskowej i edukacji ekologicznej. Niewątpliwie do nich zaliczyć należy teologiczną cnotę milości oraz kardynalne cnoty roztropności i umiarkowania, które należy u najmłodszych lat upowszechniać w wychowaniu ekologiczno - moralnym chrześcijanina.

Cnota roztropności określana jest $\mathrm{w}$ chrześcijańskiej etyce jako umiejętność prawego rozumu rozpoznawania i wybierania najwłaściwszych sposobów postępowania. Nic dziwnego, że chrześcijańscy moraliści uważają, że degradacja przyrody wynika z degradacji moralnej i duchowej współczesnego człowieka. Właściwe ukształtowanie cnoty roztropności pozwala na oszczędne i przemyślane korzystanie z dóbr naturalnego środowiska. ${ }^{39}$

Jednak cnotą, która już samej definicji, idealnie pasuje do idei chrześcijańskiej etyki środowiskowej jest cnota umiarkowania. Życie we właściwym umiarze pozwala „zahamować nadmierną konsumpcję, która jest wynikiem działania w sposób nieuporządkowany pierwotnych popędów ludzkich i przyczynia się do zakłócenia równowagi ekologicznej" ${ }^{40}$ poprzez nadmierną rabunkową gospodarkę, wynikającą z konsumpcyjnego stylu życia współczesnego homo sapiens.

Ibidem, s. 229.

38 J. BAJDA, Grzech ekologiczny (Próba podejścia do zagadnienia), op. cit., s. 73.

39 S. DZIEKoński, Wychowanie ekologiczne w religii chrześcijańskiej, op. cit., s. 69.

40 Ibidem, op. cit., s. 69-70. 
Na ogół chrześcijańscy moraliści uważają, iż powinność domagania się szacunku dla człowieka jest jednocześnie podstawą szacunku dla środowiska przyrodniczego. Postulują przy tym, aby wszelkie relacje osobowe afirmujące ludzką godność wspierać na przykazaniu „miłuj bliźniego swego jak siebie samego”. Miłość bowiem w chrześcijaństwie jako nadrzędna wartość i pierwsza $z$ cnót teologicznych jest klamrą spinającą inne cnoty. Stanowi bowiem najwyższe kryterium godności osobowej - człowieka regulując nasze postępowanie w stosunku do drugich, w tym i do środowiska przyrodniczego.

Jak wcześniej ukazałem niszczenie przyrody w katolickiej etyce jest grzechem, w związku z tym poczyniono różne próby opracowania swoistych przykazań ekologicznych, które nawiązywałyby do autorytetu biblijnego Dekalogu.

\subsection{Dekalog ekologiczny}

W celu zapobieżenia degradacji przyrody na konferencji Żydów i chrześcijan w październiku 1982 roku, opracowano dziesięć przykazań ekologicznych (Dekalog ekologiczny). Oto one:

1. „Jam jest Pan Bóg twój, który stworzył niebo i ziemię.

Weź pod uwagę, że w tym stworzeniu jesteś moim partnerem.

Obchodź się więc troskliwie z powietrzem, wodą, ziemią

i zwierzętami, tak jakby byli to twoi bracia i siostry.

2. Weź pod uwagę, że dając ci życie, dałem ci także odpowiedzialność, wolność i ograniczone rezerwy surowców ziemi.

3. Nie okradaj przeszłości. Szanuj swoje dzieci, dając im możliwość długiego życia.

4. Rozbudzaj w swoich dzieciach miłość do natury.

5. Rozważ, że ludzkość może wprawdzie używać technologii, lecz raz zniszczonego życia nie może stworzyć na nowo.

6. Zatroszcz się o to, aby w twojej wsi, twoim mieście, twoim kraju tworzyły się grupy, które będą się z zaangażowaniem starały o to, aby zapobiec grożącym katastrofom.

7. Odsuń się od wszelkich broni, które powodują nie dające się naprawić zniszczenia w podstawowych uwarunkowaniach życia.

8. Ćwicz samodyscyplinę także przy małych decyzjach w swoim życiu.

9. Znajdź w twoim cotygodniowym dniu wypoczynku - sabacie czy niedzieli - czas, aby żyć ze światem, a nie tylko go używać.

10. Pomyśl o tym: nie posiadasz ziemi - jesteś tylko jej stróżem (opiekunem)"41. Dekalog ten jest świadectwem stosunku Kościoła do problemów ekologicznych i zarazem zachętą dla wszystkich chrześcijan, Żydów oraz wyznawców innych religii, aby poważnie potraktowali potrzebę ochrony przyrody.

${ }_{41}$ J. Bohdanowicz, Ku cywilizacji ekorozwoju, Gdańsk 1998, s. 39-40. 


\section{Zakończenie}

Na zakończenie chciałbym ostatecznie podsumować moje główne rozważania. Jak wiadomo, dobrem najwyższym w chrześcijańskiej etyce jest Bóg. Stanowi On więc również summum bonum w mojej teocentrycznej koncepcji chrześcijańskiej etyki środowiskowej. To Bóg stworzył człowieka i przyrodę, którą utrzymuje cały czas w istnieniu, jednak tylko człowieka ukształtował na swoje podobieństwo i obdarzył pierwiastkiem duchowym. Środowisko przyrodnicze jest Bożym darem, o który człowiek powinien dbać i zachowywać w należytej równowadze. Natomiast wartością auteteliczną, nadrzędną w mojej koncepcji teocentrycznej etyki ekologicznej, jest człowiek a w zasadzie jego godność stanowiąca moralną normę, domagającą się szacunku, która również warunkuje konieczność zachowania jego zdrowia i życia, będącego celem samym w sobie.

W zasadzie z perspektywy tomistycznej antropologii wartością instrumentalną, a więc taką, która jest środkiem do osiągnięcia celu nadrzędnego (wartości nadrzędnej) jest niezniszczone środowisko przyrodnicze, ponieważ bez niego nie ma możliwości zachowania zdrowia i życia człowieka. Ponadto przyroda pełni również rolę środka w urzeczywistnianiu zadanej człowiekowi doskonałości moralnej oraz duchowej i dostępuje uczestnictwa w przysługującej mu godności. Od tego momentu przestaje być tylko biologicznym tworem lecz w pewnym sensie "się humanizuje", aczkolwiek pozostaje nadal w służebnej relacji do człowieka. ${ }^{42}$

W miejscu tym jednak pojawia się zasadnicza kwestia, która wykracza zdecydowanie poza rozwiązania czysto użytkowe, bowiem wyrasta z chrześcijańskiego teocentryzmu. Wedle argumentu teologicznego natura posiada wartość bowiem cechuje się osobliwą godnością, polegającą na tym, że jest odzwierciedleniem samego Boga i Jego godności. Wartość natury jest jednak mniejszej rangi niż u człowieka, który stanowi wartość nadrzędną.

Nigdy jednak nie osiągniemy celu nadrzędnego (wartości nadrzędnej) jeśli nie zmienimy własnego stylu życiu. Dlatego niezbędne jest ukształtowanie sumienia ekologicznego oraz niezbędnych dyspozycji działania, sprawności moralnych, a więc cnót, które w pewnym sensie są specyficznymi wartościami - środkami prowadzącymi nas do osiągnięcia równowagi w środowisku przyrodniczym, które gwarantuje godne zachowanie ludzkiego zdrowia i życia. Te wartości - środki to roztropność i umiar, natomiast klamrą, je spinającą jest milość, bez której nic w świecie na dobre nie zaistnieje.

$\mathrm{Na}$ podstawie powyższych rozważań, należy więc przyjąć, że idea wyższości czlowieka nad przyrodą, nie jest tożsama $z$ ideą bezwzględnej dominacji człowieka nad środowiskiem przyrodniczym. Wręcz przeciwnie człowiek jako byt stanowiący „koronę stworzenia”, jest szczególnie odpowiedzialny za cały ota-

42 T. ŚLIPKo, Granice życia. Dylematy wspólczesnej bioetyki, Kraków 1994, s. 39. 
czający go świat przyrody, który powinien szanować i dbać, gdyż jest on darem Stwórcy dla człowieka i powinien zostać zachowany jako dziedzictwo dla przyszłych pokoleń, naturalnie przy współudziale edukacji ${ }^{43}$.

\title{
The theo-centrical model for environmental ethics
}

\author{
SUMMARY
}

The author presents in his article the following problems: the theo-centrical aspect of environmental ethics, the anthropological foundations of eiwironmental ethics in Tomism, problems of protecting the social natural environment in the light of morat theology, natural law in its ecological dimensions, the understand of conscience in this field of study, sins against the environment, ecological aspects of arotology, and the Decalogue for the environment.

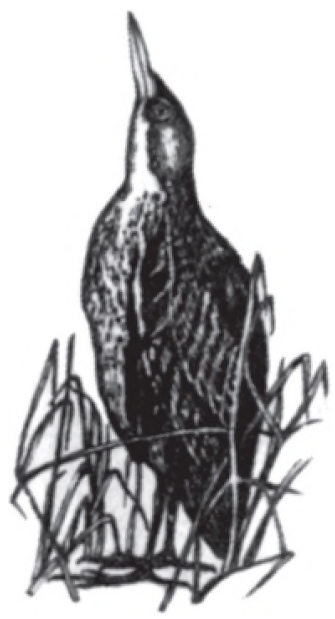

$\mathrm{Baqk}$

43 Por. K. PiRecki, Dylematy edukacji ekologicznej, (w:) Bioetyka i ekofilozofia, pod red. J. Jaronia, Siedlce 1999, s. 61-75. 